Kio J. Med. 22: 109-122, 1973

\title{
TOLERANCE DOSE OF THE SPINAL CORD ON RADIATION MYELOPATHY
}

\author{
TETSUYA NAGASE, YUKIFUSA TANAKA, TADASHI WADA \\ and TOKIO FUJIMAKI
}

Department of Radiology, School of Medicine, Keio University, Tokyo, Japan

(Received for publication September 17, 1973)

\begin{abstract}
Radiation myelopathy has developed in 9 cases among irradiated patients as a side effect following radiotherapy for malignant tumors. The dose to the spinal cord was 5,000-10,000 rads, the over all treatment time 42-71 days. Several causative factors of the radiation myelopathy were picked up.

The degree of radiation influences in the spinal cord seem to be time-dose dependent, as reported by Boden and Pallis. A recommended tolerance dose to spinal cord was over 4,000 rads and over 5,000 rads according to Tsuya's and Friedman's reports respectively and an NSD* of 1,300 rets and 1,500 rets was recommended by Maier and Phillips respectively. From the data presented it is apparent that degree of occurrence of radiation myelopathy depends greatly on fractionation and irradiation dose. When the patients are treated in more than 21 fractions at a daily dose of 200 rads and the dose to the spinal cord irradiated is more than 5,000 rads, it can be considered to be the critial level for radiation myelopathy.
\end{abstract}

\section{INTRODUCTION}

Recent development of radiotherapy for malignant tumors coupled with the life prolongation of the tumor patients has focused a light on radiation myelopathy seen as a side effect of this therapy.

Statistics made in foreign lands shows that this disease occurs at the incidence rate of several per cent. In Japan until present radiation myelopathy has been considered as a rare complication, but now it tends to be increasing. Warren ${ }^{1,2}$ reported that the central nervous system was not affected at all for its

\footnotetext{
* NSD $=$ Nominal Standard Dose by Ellis26

$\mathrm{NSD}=\mathrm{DN} \times \mathrm{N}^{-0.24} \times \mathrm{T}^{-0.11}$

DN: Total dose in rads

$\mathrm{N}$ : Number of fraction

$\mathrm{T}:$ Overall treatment time
} 
low radiosensitivity by the dose of ordinary level irradiated to malignant tumors. However, the further studies revealed that the central nervous system might be one of the tissues that have high radiosensitivity to irradiation in the functional level. (Tsuya).$^{3,4,5}$

Ahlbom $^{7}$ (1941) referred to this disease first, and there are a moderate number of reported cases in the literature. According to these reports it was concluded that the factors causing radiation myelopathy were closely related with the irradiation dose, the overall treatment time, the number of fractions, the radiation energy, the length of the spinal cord included in the field of irradiation, and the individual tolerance differences.

The present paper describes an analysis of nine cases of radiation myelopathy observed in this hospital which received radiotherapy for malignant tumors

Table 1

Radiation myelopathy cases in our hospital

\begin{tabular}{|c|c|c|c|c|c|c|c|c|c|c|}
\hline Case & Sex & Age & Diagnosis & $\begin{array}{l}\text { Radia- } \\
\text { tion } \\
\text { energy }\end{array}$ & $\begin{array}{c}\text { Treat- } \\
\text { ment } \\
\text { of } \\
\text { portals }\end{array}$ & $\begin{array}{c}\text { Field } \\
\text { Size/ } \\
\text { cm }\end{array}$ & $\begin{array}{l}\text { Loca- } \\
\text { tion } \\
\text { of } \\
\text { spinal } \\
\text { treat- } \\
\text { ed }\end{array}$ & $\begin{array}{c}\text { Tumor } \\
\text { dose } \\
\text { /rad }\end{array}$ & $\begin{array}{l}\text { Over- } \\
\text { all } \\
\text { time } \\
\text { /days }\end{array}$ & $\begin{array}{l}\text { No. of } \\
\text { frac- } \\
\text { tion- } \\
\text { ation }\end{array}$ \\
\hline 1 & M & 68 & $\begin{array}{l}\text { Ca. of the } \\
\text { lung }\end{array}$ & $6 \mathrm{MeV} \mathrm{X}$ & 2 & $8 \times 12$ & $\mathrm{~T}_{2}-\mathrm{T}_{8}$ & 7,000 & 42 & 35 \\
\hline 2 & $\mathbf{F}$ & 56 & $\begin{array}{l}\text { Malig. } \\
\text { struma }\end{array}$ & $\mathrm{Co}-60$ & 1 & $6 \times 6$ & $\mathrm{C}_{5}-\mathrm{T}_{1}$ & 6,350 & 64 & 39 \\
\hline $\mathbf{3}$ & $\mathbf{M}$ & 67 & $\begin{array}{l}\text { Ca. of the } \\
\text { lung }\end{array}$ & $6 \mathrm{MeV} \mathrm{X}$ & 2 & $\begin{array}{r}11.8 \times \\
7.2\end{array}$ & $\mathrm{~T}_{4}-\mathrm{T}_{8}$ & 12,000 & 71 & 57 \\
\hline 4 & $\mathbf{F}$ & 40 & $\begin{array}{l}\text { Ca. of the } \\
\text { gingiva }\end{array}$ & $6 \mathrm{MeV} \mathrm{X}$ & 2 & $7 \times 7$ & $\mathrm{C}_{1}-\mathrm{C}_{8}$ & 7,000 & 46 & 35 \\
\hline 5 & $\mathbf{M}$ & 45 & $\begin{array}{l}\text { Ca. of the } \\
\text { pharynx }\end{array}$ & $200 \mathrm{KVX}$ & 2 & $8 \times 10$ & $\mathrm{C}_{1}-\mathrm{C}_{6}$ & 10,300 & 69 & 47 \\
\hline 6 & $\mathbf{M}$ & 39 & $\begin{array}{l}\text { Medias- } \\
\text { tin tumor }\end{array}$ & $6 \mathrm{MeV} \mathrm{X}$ & 2 & $\begin{array}{r}11.2 \times \\
14\end{array}$ & $\mathrm{~T}_{2}-\mathrm{T}_{8}$ & 7,200 & 45 & 34 \\
\hline 7 & $\mathbf{F}$ & 46 & $\begin{array}{l}\text { Malig. } \\
\text { struma }\end{array}$ & $\mathrm{Co}-60$ & 2 & $6 \times 8$ & $\mathrm{C}_{5}-\mathrm{T}_{2}$ & 10,200 & 68 & 46 \\
\hline 8 & $\mathbf{F}$ & 29 & $\begin{array}{l}\text { Ca. of the } \\
\text { breast }\end{array}$ & $6 \mathrm{MeV} \mathrm{X}$ & 1 & $5 \times 15$ & $\mathrm{~T}_{2}-\mathrm{T}_{9}$ & 6,900 & 50 & 32 \\
\hline 9 & M & 29 & $\begin{array}{l}\text { Medias- } \\
\text { tinal tumor }\end{array}$ & $6 \mathrm{MeV} \mathrm{X}$ & 2 & $\begin{array}{r}14.5 \times \\
10.5\end{array}$ & $C_{6}-T_{8}$ & 8,000 & 48 & 40 \\
\hline
\end{tabular}


during the period of 1966-1972 and is intended to supply further clinical information in the hope that it will help more precisely to define the radiosensitivity of the spinal cord.

\section{MATERIALS AND METHOD}

During the past six years (1966-1972) nine patients of radiation myelopathy were observed in our hospital as a result of radiotherapy for malignant tumors. These nine patients were selected from about 600 patients with malignant tumor who had received radiotherapy, indicating that the incidence rate of this disease was about 1.5 per cent.

The clinical manifestations of the myelopathy grouped them into the chronic

\begin{tabular}{|c|c|c|c|c|c|c|c|}
\hline $\begin{array}{l}\text { Dose } \\
\text { to } \\
\text { spinal } \\
\text { cord } \\
\text { /rad }\end{array}$ & $\underset{\text { /rets }}{\text { N. S. D. }}$ & $\begin{array}{l}\text { Latent } \\
\text { interval }\end{array}$ & $\begin{array}{c}\text { Myelopathy } \\
\text { type }\end{array}$ & Clinical findings & $\begin{array}{l}\text { Myelo- } \\
\text { graphy }\end{array}$ & $\begin{array}{l}\text { Protein } \\
\text { in liquor }\end{array}$ & $\begin{array}{c}\text { Statur } \\
\& \\
\text { survival }\end{array}$ \\
\hline 7,000 & 1,970 & $6 \mathrm{mo}$ & transient & Lehrmitte's sign & - & - & $\begin{array}{l}\text { Dead } \\
4.5 \mathrm{y}\end{array}$ \\
\hline 5,600 & 1,470 & $6 \mathrm{mo}$ & progressive & $\begin{array}{l}\text { Brown-Sequard } \\
\text { Syndrome } \\
\text { (below } \mathrm{T}_{5} \text { ) }\end{array}$ & Normal & $13 \mathrm{mg} / \mathrm{dl}$ & $\begin{array}{l}\text { Alive } \\
8 \mathrm{mo}\end{array}$ \\
\hline 10,000 & 2,380 & $18 \mathrm{mo}$ & progressive & $\begin{array}{l}\text { Brown-Sequard } \\
\text { Syndrome } \\
\text { (below } \mathrm{T}_{7} \text { ) }\end{array}$ & Normal & $125 \mathrm{mg} / \mathrm{dl}$ & $\begin{array}{l}\text { Dead } \\
8 \mathrm{mo}\end{array}$ \\
\hline 6,200 & 1,730 & $8 \mathrm{mo}$ & progressive & $\begin{array}{l}\text { Paresthesia right } \\
\text { hand \& leg }\end{array}$ & Normal & $46 \mathrm{mg} / \mathrm{dl}$ & $\begin{array}{l}\text { Dead } \\
10 \mathrm{mo}\end{array}$ \\
\hline 9,000 & 2,220 & $38 \mathrm{mo}$ & progressive & $\begin{array}{l}\text { Paresthesia both } \\
\text { legs }\end{array}$ & Normal & $80 \mathrm{mg} / \mathrm{dl}$ & $\begin{array}{l}\text { Dead } \\
3 \mathrm{y}\end{array}$ \\
\hline 7,000 & 2,100 & $3 \mathrm{mo}$ & transient & Lehrmitte's sign & & & $\underset{2 \mathrm{y}}{\text { Alive }}$ \\
\hline 7,000 & 1,970 & $12 \mathrm{mo}$ & progressive & $\begin{array}{l}\text { Brown-Sequard } \\
\text { Syndrome } \\
\text { (below } \mathrm{T}_{5} \text { ) }\end{array}$ & Normal & Normal & $\begin{array}{l}\text { Dead } \\
3 \mathbf{y}\end{array}$ \\
\hline 5,600 & 1,590 & $26 \mathrm{mo}$ & progressive & $\begin{array}{l}\text { Brown-Sequard } \\
\text { Syndrome } \\
\text { (below } \mathrm{T}_{3} \text { ) }\end{array}$ & $\begin{array}{l}\text { Ad- } \\
\text { hesion }\end{array}$ & $24 \mathrm{mg} / \mathrm{dl}$ & $\begin{array}{l}\text { Dead } \\
18 \mathrm{mo}\end{array}$ \\
\hline 8,000 & 2,150 & $6 \mathrm{mo}$ & progressive & $\begin{array}{l}\text { Paresthesia right } \\
\text { hand \& both legs }\end{array}$ & Normal & $35 \mathrm{mg} / \mathrm{dl}$ & $\begin{array}{r}\text { Alive } \\
4.5 \mathrm{y}\end{array}$ \\
\hline
\end{tabular}


progressive type ( 6 cases) and the transient type (3 cases). The diagnosis of these 9 cases were cancer of the lung ( 2 cases), malignant struma ( 2 cases), mediastinal tumor ( 2 cases), cancer of the breast ( 1 case) cancer of the pharynx ( 1 case) and cancer of the gingiva ( 1 case).

From the viewpoint of radiation energy, 6 cases were irradiated with supervoltage x-rays of $6 \mathrm{MeV}$ ( $\mathrm{NEC}$ ), 2 cases received gamma rays with Co-60 teletherapy units and 1 case received grid therapy of conventional $\mathbf{x}$-rays. The $\mathbf{x}$-ray treatment was given through two field portals with the exception of two cases of breast cancer and struma. The daily dose was 200 rads, weekly dose $1,000-1,200$ rads and total dose 6,000-12,000 rads which were sufficient to eradicate malignant tumors. The number of fractions ranged 32-57 and overall treatment time 42-71 days.

Irradiation field was from $6 \times 8 \mathrm{~cm}$ to $11.2 \times 14 \mathrm{~cm}$. The smaller field served for tumor of head and neck, the larger field served for mediastinal tumors and cancer of the lung. The dose irradiated to the spinal cord was from 5,600 rads to 10,000 rads (Table 1 ).

In the present series the latent period from the completion of therapy to the

Table 2

Incidence rate of radiation myelopathy

\begin{tabular}{|c|c|c|c|}
\hline Author & $\begin{array}{l}\text { Tumor patients } \\
\text { for examination }\end{array}$ & $\begin{array}{l}\text { Patients with } \\
\text { radiation myelopathy }\end{array}$ & $\%$ \\
\hline Ahlbom (1941) & 235 cases & 4 cases & 1.7 \\
\hline Greenfield (1948) & 180 cases & 3 cases & 1.7 \\
\hline Boden (1948) & 161 cases & 10 cases & 6.2 \\
\hline Jacobsson $^{243}$ (1951) & 322 cases & 13 cases & 4 \\
\hline Friedman (1954) & 100 cases & 10 cases & 10 \\
\hline Dynes (1960) & 800 cases & 10 cases & 1.3 \\
\hline Parker (1963) & 125 cases & 6 cases & 5 \\
\hline Vaeth (1964) & 322 cases & 3 cases & 0.9 \\
\hline Locksmith (1968) & 48 cases & 6 cases & 12.5 \\
\hline Philips (1969) & 350 cases & 3 cases & 0.9 \\
\hline $\operatorname{Tan}^{253}(1969)$ & 22 cases & 3 cases & 13.3 \\
\hline Maier (1969) & 343 cases & 15 cases & 4.5 \\
\hline Egawa (1970) & 60 cases & 4 cases & 6.7 \\
\hline
\end{tabular}


earliest symptoms was from 3 months to 38 months. It was within one year for 6 cases and over one year for 3 cases, the average being 14 months. Tsuya et al's observation that the latent period was, in general, shorter in the transient type than in the chronic progressive type coincides with our findings that the latent period in the transient type was 3-6 months which was shorter than in the chronic type (Table 3 ).

Table 3

Radiation myelopathy and its latent period

\begin{tabular}{l|c|c}
\hline \multicolumn{1}{c|}{ Author } & Cases & Latent period \\
\hline Greenfeld (1948) & 3 cases & $3.5-5$ months \\
\hline Boden (1948) & 10 cases & $1-15$ months \\
\hline Boden (1950) & 3 cases & $12-17$ months \\
\hline Itabashi (1957) ${ }^{21)}$ & 2 cases & $4.5-15$ months \\
\hline Dynes (1960) & 10 cases & $7-50$ months \\
\hline Pallis (1961) & 5 cases & $7-18$ months \\
\hline Atkins (1966) & 14 cases & $6-29$ months \\
\hline Kristensson (1967) & 5 cases & $7-40$ months \\
\hline Regan (1968) & 10 cases & $5-26$ months \\
\hline Locksmith (1968) & 6 cases & $12-35$ months \\
\hline Phillips (1969) & 3 cases & $10-13$ months \\
\hline Egawa (1970) & 5 cases & 50 days -10 months \\
\hline
\end{tabular}

\section{CLINICAL FEATURES}

The transient type of this series showed a Lehrmitte's sign. Symptoms of the chronic progressive type were accompanied by sensory and motor deficits. A Brown-Séquard syndrome was manifested in 5 cases out of 9 . The onset presented often with a paresthesia tingling, and an abnormal sensation of upper or lower extremities. Pain radiating down the leg was another complaint. These initial symptoms were accompanied by sensory changes with loss in pain and temperature perception on one side of the body and subsequently on the other. Dysfunction of bladder and rectum was evident, often together with complete paralysis seen at the segment of the spinal cord irradiated. There were several cases, how- 
ever, of incomplete paralysis. A Brown-Séquard syndrome was observed in 5 cases out of 7 of the chronic type, and 2 cases manifested incomplete paralysis. The transient type underwent spontaneous resolution of symptoms within 5-6 months after the onset in 2 cases, while no relief was observed in the chronic progressive type.

The radiation myelopathy is referred as a dangerous sequela where death rate within 2 years is very high and the patients die rather from infections via respiratory and urinary tracts due to paralysis than from malignant tumors. In the present series fatal outcome was observed in 5 cases out of 9 . Three died from radiation myelopathy and 2 from other fatal causes.

Clinical laboratory examinations revealed the following features.

1. There was no destructed image in the x-ray photographs of the spine.

2. The spinal fluid was normal in all cases with the exception of slight increase of the concentration of protein $(13-125 \mathrm{mg} / \mathrm{dl})$.

3. Contrary to the previous findings that myelogram examination demonstrated no difficulty in passage, our 2 cases showed compression and congestion due to adhesions.

4. Tendon reflex (P.S.R.) was increased in all cases and abnormal in 7 cases.

Criterions for the diagnosis of radiation myelopathy

The presice diagnosis of radiation myelopathy is often difficult to determine because of its long latent interval between completion of radiotherapy and onset of symptoms and also because the disease which are most likely to lead to it are malignant tumors that induce paralysis due to metastasis to spine, thus requiring the appropriate procedure to avoid misinterpretation. We decided several preliminary criterions for diagnosing radiation myelopathy as follows;

1. The spinal cord is included in the field of irradiation.

2. The latent period from completion of radiotherapy to the earliest symptoms ranges from several months to three years.

3. Development of a neurological lesion is confined within spinal cord segments submitted to irradiation or below these.

4. Although consideration must be also given to the field of irradiation, the irradiation dose, the number of fractions, and the overall treatment time, the dose to the spinal cord should be 4,000-5,000 rads or more.

5. The symptoms are manifested by sensory and motor deficits that gradually develop, and Lehrmitte's sign and a Brown-Séquard syndrom are observed in some cases. No relief of symptoms is observed with the 
exception of the transient type.

6. Examinations of the spinal fluid reveal either an almost normal condition or a slight increase of protein.

7. In general difficulty in passage is not observed in myelography.

8. Metastases to the spine or carcinomatous neuropathy should be excluded from the diagnosis.

Although there are many reports in which the critical dose to induce the irradiation myelopathy is less than $4,000 \mathrm{rads}$, it is a common observation that the critical dose is $4,000-5,000$ rads or more in a daily dose of 200 rads and in many fractions.

\section{Pathology}

Pathological examinations in this series showed that the main lesions were limitted to the field included in the irradiation. Spinal cord showed degeneration, necrosis, and atrophy. In the blood vessel there were chronic changes including hypertrophy of the intima, fibrosis of the wall and hyalin degeneration. The lesions of the spinal cord were marked particularly in white substances, in which demyelination was evident at anterior, posterior or left lateral columns. In comparison to white substances grey substances underwent relatively fair damage but some tissues often showed a destruction. Preliminary autopsy performed in 2 cases of this series will be illustrated in case reports. Photograph 1 taken for these cases demonstrated a clear demyelination at bilateral and posterior columns, hypertrophy of intima of blood vessel, and increased glia cells. These findings are to be noted in contrast to Jones et al's findings that there was no demonstrable lesions by autopsy performed on the patients with the transient type after the relief of the symptoms.

\section{Illustrative case reports}

One case of transient type and one of progressive type of illustrous radiation myelopathy are reported in this paper.

Case 1: a 68-year-old male was admitted to our hospital in 1966. A chest roentgenogram showed a large mass in the right lung and he was diagnosed as cancer of the lung. At a daily dose of $200 \mathrm{rads}$ he received a tumor dose of 7,000 rads in 42 days, in 35 fractions on $6 \mathrm{MeV}$ Linac $\mathrm{x}$-rays through $8 \times 12 \mathrm{~cm}$ opposing anterior and posterior fields. He did well during 6 months after completion of therapy, but on May 1968 he noted paresthesia at lower extremities together 
with Lehrmitte's sign manifested by motor deficit in the left lower extremity. The disease was not further aggravated and underwent spontaneous resolution of symptoms within 5-6 months. Next 3 years he did quite well without recurrence of cancer of the lung nor metastasis of lung tumors and free from syrnptoms of radiation myelopathy up to May, 1972, when he observed blood in sputum and a chest roentgenogram showed a mass ascribed to recurrent tumor in the right lower lung. He had a fatal outcome in spite of radiotherapy. Clinically this case is grouped as a transient type of radiation myelopathy. The latent period from completion of therapy to onset of the disease was about 6 months and the dose to the spinal cord was 7,000 rads.

Autopsy showed the lesions ascribed to recurrence of lung carcinoma manifested by demyelination in posterior and bilateral columns, vitreous hypertrophy in intima of capillary blood vessel and increased glia cells. This case is an example which has different pattern from Jones et al's findings that in a patient of transient type the spinal cord irradiated had not underwent lesions.

Case 2: a 57-year-old male was admitted to our hospital. A chest roentgenogram showed a mass ascribed to tumors in the right lung and he was diagnosed as cancer. Operation was impossible because of his heart disease. $\mathrm{He}$ was then referred for radiotherapy. He was treated with $6 \mathrm{MeV}$ Linac $\mathrm{x}$-rays through opposing anterior and posterior portals measuring $11.8 \times 7.2 \mathrm{~cm}$ and in $\mathbf{7 1}$ days, in $\mathbf{5 7}$ fractions, and in a daily dose of 200 rads, he received a

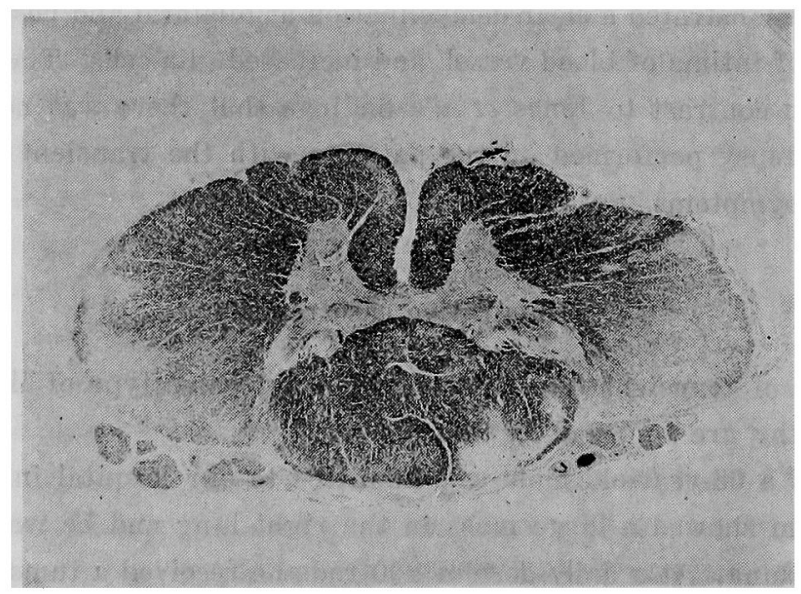

Fig. 1 (case 1) Photo-micrograph of section through the Spinal cord. Destruction of both lateral columns. 


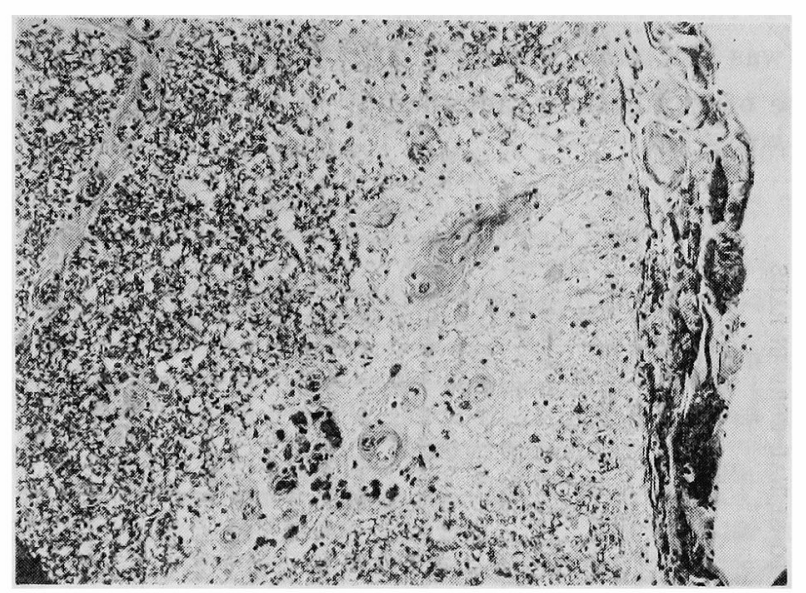

Fig. 2 (case 1) Spinal cord showing fibrosis, in places hyalin, thicking of the vessel walls, destruction of white matter and cellular infiltration.

tumor dose of 12,000 rads. The dose to the spinal cord might be about 10,000 rads. Tumor shadow on the picture disappeared completely and the prognosis was better till 18 months after the therapy, when he became aware of loss of sensory and temperature perception. The myelopathy was progressing and BrownSéquard syndrom developed at a level lower than left $\mathrm{T}_{7}$. The examination of spinal fluid revealed an increase of the concentration of protein $(125 \mathrm{mg} / \mathrm{dl})$. Myelography showed no difficulty in passage. He was grouped as a progressive type of radiation myelopathy and despite further treatment he had a fatal outcome 8 months after the onset. Autopsy showed a wide demyelination spreading over posterior to lateral columns of the spinal cord irradiated to the $\mathrm{T}_{7}-\mathrm{T}_{9}$ level.

\section{DISCUSSION}

For the relation between the irradiation dose and radiation myelopathy, Boden $^{10,11}$ (1948) established a tolerance dose of 3,500 rads in 17 days with larger fields and a tolerance dose of 4,500 rads to the spinal cord in 17 days with smaller fields and it must be not excess 2,000 rads daily. Pallis et al established a tolerance dose 20 per cent lower than those which Boden suggested for both large and small fields. These tolerance doses are actually considered to be the indicator when we determine the irradiation dose and overall treatment time (Figs. 3 and 4). Boden et al presented several cases of radiation myelopathy subsequent to 1,800 
rads and 2,040 rads in single treatment, where in 10 cases out of 13 the dose to the spinal cord was less than 4,000 rads. If radiation myelopathy develops upon such a small dose of irradiation, radiotherapy of malignant tumors would require a severe control.

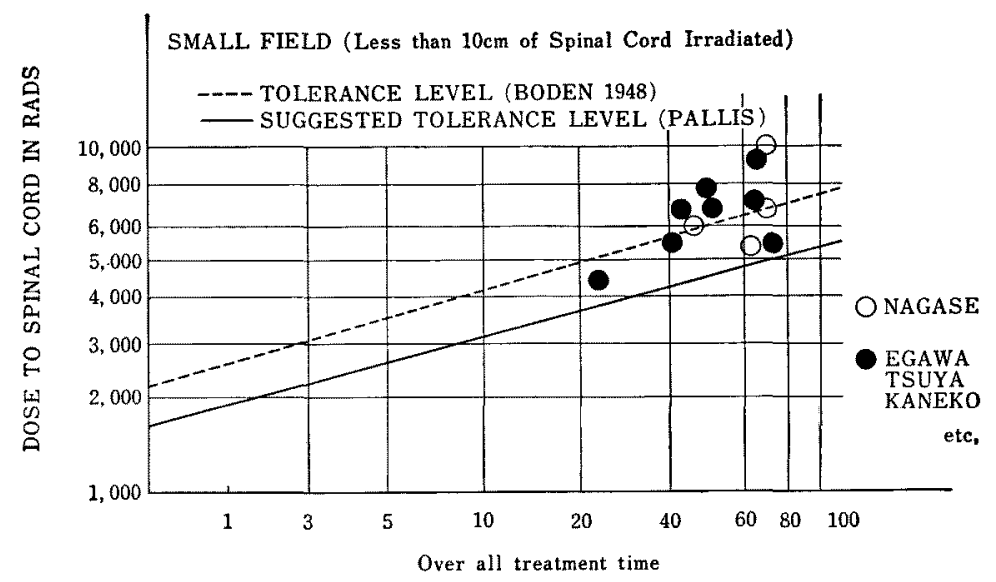

Fig. 3 Radiation myelopathy (Dose-time relationship).

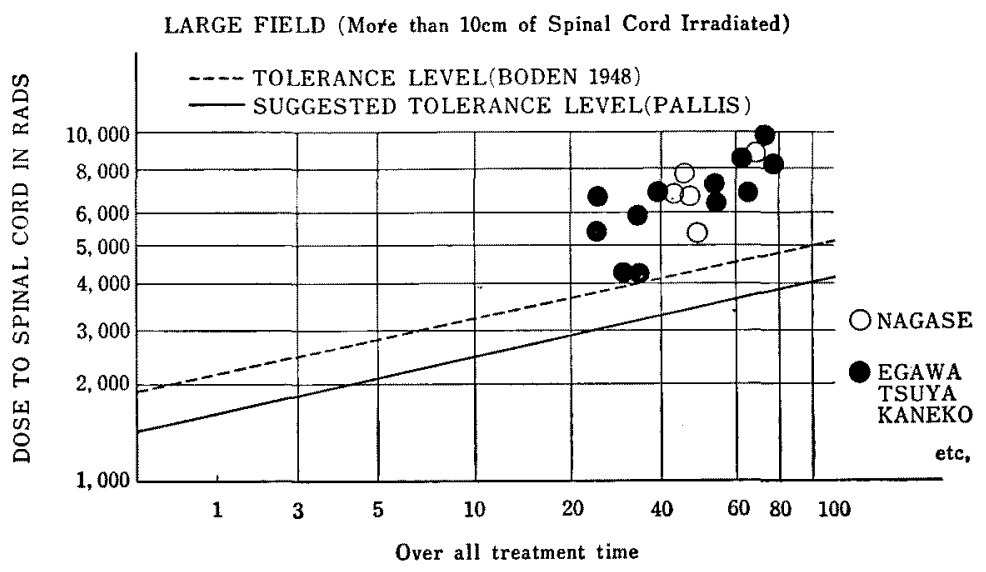

Fig. 4 Radiation myelopathy (Dose-time relationship).

Classical work from Greenfield ${ }^{9}$ (1948) and to Kaneko ${ }^{6}$ (1972) made on the radiation myelopathy is referred in Table 4 in which the dose to the spinal cord is shown. This indicates that the dose required to develop the disease is in the level higher than 4,000 rads according to the authors including Greenfield, 
Table 4

Radiation myelopathy and the dose to the spinal cord

\begin{tabular}{l|c|c}
\hline \multicolumn{1}{c|}{ Author } & $\begin{array}{c}\text { Cases of radiation } \\
\text { myelopathy }\end{array}$ & Dose to the spinal cord \\
\hline Greenfield (1948) & 3 cases & $4,454-6,480 \mathrm{R}$ \\
\hline $\begin{array}{l}\text { Boden (1948) } \\
\text { Boden (1950) }\end{array}$ & 13 cases & $\begin{array}{l}\text { Single } \\
\text { Fractionation } 3,200-2,250 \mathrm{R} \\
3,000-5,250 \mathrm{R}\end{array}$ \\
\hline Dynes (1960) & 10 cases & $2,500-6,000 \mathrm{R}$ \\
\hline Pallis (1961) & 5 cases & $2,850-8,700 \mathrm{R}$ \\
\hline Kozuka ${ }^{23)}(1964)$ & 1 case & $7,000 \mathrm{R}$ \\
\hline Kristensson (1967) & 5 cases & $4,000-5,100 \mathrm{R}$ \\
\hline Locksmith (1968) & 6 cases & $3,870-4,370 \mathrm{R}$ \\
\hline Regan (1968) & 10 cases & $4,000-6,900 \mathrm{rads}$ \\
\hline Phillips (1969) & 3 cases & $3,300-7,000 \mathrm{rads}$ \\
\hline Egawa (1970) & 5 cases & $6,000-9,969 \mathrm{R}$ \\
\hline Tsuya (1970) & 2 cases & $4,000-6,000 \mathrm{rads}$ \\
\hline Kaneko (1972) & 3 cases & $4,320-8,066 \mathrm{rads}$ \\
\hline
\end{tabular}

Table 5

Incidence rate of radiation myelopathy relative to the dose irradiated to the spinal cord

\begin{tabular}{|c|c|c|c|c|c|}
\hline & Dose & Cases & $\%$ & $\%$ & $\%$ \\
\hline 1 & $-2,000 \mathrm{rad}$ & 5 cases & $9 \%$ & \multirow{3}{*}{$\begin{array}{l}20 / 53 \\
38 \%\end{array}$} & \multirow{4}{*}{$\begin{array}{r}28 / 53 \\
52 \%\end{array}$} \\
\hline 2 & $2,100-3,000 \mathrm{rad}$ & $4 \prime \prime$ & $8 \%$ & & \\
\hline 3 & $3,100-4,000 \mathrm{rad}$ & $11 \prime \prime$ & $20 \%$ & & \\
\hline 4 & $4,100-5,000 \mathrm{rad}$ & $8 \prime \prime$ & $15 \%$ & \multirow{7}{*}{$\begin{array}{l}33 / 53 \\
62 \%\end{array}$} & \\
\hline 5 & $5,100-6,000 \mathrm{rad}$ & 511 & $9 \%$ & & \multirow{6}{*}{$\begin{array}{l}25 / 53 \\
47 \%\end{array}$} \\
\hline 6 & $6,100-7,000 \mathrm{rad}$ & $10 \prime \prime$ & $19 \%$ & & \\
\hline 7 & $7,100-8,000 \mathrm{rad}$ & 411 & $8 \%$ & & \\
\hline 8 & $8,100-9,000 \mathrm{rad}$ & 211 & $5 \%$ & & \\
\hline \multirow[t]{2}{*}{9} & $9,100-10,000 \mathrm{rad}$ & $4 \prime \prime$ & $8 \%$ & & \\
\hline & Total & 53 cases & & & \\
\hline
\end{tabular}


Kristenson, ${ }^{13}$ Reagan ${ }^{8}$ and Egawa. Some of the patients included in the study of Dynes, ${ }^{15}$ Phillips, ${ }^{16}$ Pallis ${ }^{12}$ developed the disease at a dose less than 4,000 rads. Atkins $^{22}$ reported that radiation myelopathy developed in 4 patients even at a dose of 1,900 rads.

The dose of irradiation thus varied over a wide range. The further analysis was made on the causative factor for this variance. The relation between dose to the spinal cord and incidence rate of the radiation myelopathy in 53 cases included in the study of Nagase, Tsuya, Egawa, ${ }^{14}$ Kaneko, Atkins, Phillips, Pallis, and Locksmith ${ }^{17}$ is shown in Table 5. The table shows that it can not be determined only by dose to the spinal cord what is the factor causing radiation myelopathy. However, when the number of fractions is taken into account, the onset of radiation myelopathy relates to the number of fractions. In the number of fractions fewer than 10 the myelopathy develops even with irradiation dose of $2,000-3,000$ rads to the spinal cord.

An increase of the number of fractions to 11-20 is followed by the onset of the disease at a dose of 3,000-5,000 rads, and the dose over 5,000 rads is the critical dose level when the number of fractions was over 21 (Table 6).

\section{Table 6}

Number of fractions and incidence rate of radiation myelopathy relative to the dose to the spinal cord

\begin{tabular}{c|c|c|c|c}
\hline \multirow{2}{*}{} & $\begin{array}{c}\text { Dose to spinal cord } \\
\text { (rad) }\end{array}$ & \multicolumn{3}{|c}{ The number of fraction } \\
\cline { 2 - 4 } & $-2,000$ & Below 10 & $11-20$ & Over 21 \\
\hline 2 & $4,100-3,000$ & 0 & 1 \\
\hline 3 & $3,100-4,000$ & 4 & 0 & 0 \\
\hline 4 & $4,100-5,000$ & 2 & 8 & 0 \\
\hline 5 & $5,100-6,000$ & 1 & 6 & 1 \\
\hline 6 & $6,100-7,000$ & 0 & 1 & 5 \\
\hline 7 & $7,100-8,000$ & 0 & 0 & 10 \\
\hline 8 & $8,100-9,000$ & 0 & 0 & 4 \\
\hline 9 & $9,100-10,000$ & 0 & 0 & 2 \\
\hline
\end{tabular}

These results indicate that when a large tumor dose of irradiation for malig- 
nant tumor at one treatment is given, the myelopathy develops even in the relatively small dose to the spinal cord. But 5,000 rads is considered to be the critical dose when ordinary irradiation is performed in such a way that a patient receives a daily dose of 200 rads, and it is necessary to consider NSD (total dose in rads, number of fraction and over all treatment time) by Ellis. The table 7 shows relationship between radiation myelopathy and rets by NSD.

Table 7

Relationship between 58 cases of radiation myelopathy and rets

\begin{tabular}{c|c|c|c|c|c}
\hline NSD (rets) & CASE & $\%$ & NSD (rets) & CASE & $\%$ \\
\hline $1201-1300$ & 1 & 2 & $1701-1800$ & 3 & 6 \\
$1301-1400$ & 3 & 6 & $1801-1900$ & 4 & 7.5 \\
$1401-1500$ & 6 & 11 & $1901-2000$ & 12 & 23 \\
$1501-1600$ & 7 & 13 & $2001-2100$ & 4 & 7.5 \\
$1601-1700$ & 5 & 9 & $2101-$ & 8 & 15 \\
\hline
\end{tabular}

\section{SUMMARY}

During the past 6 years (1966-1972), radiation myelopathy has developed in 9 patients among tumor patients as a side effect following radiotherapy for malignant tumors. The latent period was 3-38 months, the average being 14 months. The tumor dose was $6,000-12,000 \mathrm{rads}$, the overall treatment time $42-71$ days, the dose to the spinal cord 5,000-10,000 rads. Several causative factors of the radiation myelopathy were picked up.

The degree of radiation influences in the spinal cord seem to be time-dose dependent, as reported by Boden and Pallis. A recommended tolerance dose to the spinal cord was over 4,000 rads and over 5,000 rads according to Tsuya's ${ }^{19}$ and Friedman's ${ }^{20}$ reports respectively and an $\mathrm{NSD}^{26}$ of 1,300 rets and 1,500 rets was recommended by Maier ${ }^{18}$ and Phillips respectively. From the data presented it is apparent that the degree of occurrence of radiation myelopathy depends greatly on fractionation and irradiation dose. When the patients are treated in more than 21 fractions at a daily dose of $200 \mathrm{rads}$ and the dose to the spinal cord irradiated is more than 5,000 rads, it can be considered to be the critial level for radiation myelopathy, but from NSD by Ellis, tolerance dose of spinal cord is considerd over $1,300 \sim 1,400$ rets. 


\section{REFERENCES}

1. Warren, S.: Effects of radiation on normal tissue. Arch. Path. 35: 121-138, 1944

2. Warren, S.: The histopathology of radiation necrosis. Physiol. Rev. 24: 225-232, 1944

3. Tsuya, A.: Effect of irradiation on central nervous system. Clinic of cancer 16: 658-663, 1970

4. Tsuya, A.: Nervous system and irradiation. Japan J. Clinical Radiol. 12: 981-992, 1970

5. Kido, T.: Effect of gamma rays of $\mathrm{Co}-60$ on central nervous system Tissues. Nippon acta Radiologica 21: 68-86, 1971

6. Kaneko, S.: Three cases suspected of radiological myelopathy. 31 Annual General Meeting of Japan Medical Radiological Society in 1971.

7. Ahlbom, H. E.: Results of radiotherapy of hypopharyngeal cancer at Radium Hemmet. Acta Radiol. 22: 155-171, 1941

8. Reagan, T. J.: Chronic progressive radiation myelopathy. (Its clinical aspects and differencial diagnosis). J.A.M.A. 203: 106, 1968

9. Greenfield, M. M.: Post-irradiation neuropathy. Am. J. Roent. 60: 617-622, 1948

10. Boden, G.: Radiation myelitis of spinal cord. Brit. J. Radiol. 21: 464-469, 1948

11. Boden, G.: Radiation myelitis of brain stem. J. Fac. Radiologists 2: 79-94, 1950

12. Pallis, C. A. et al: Radiation myelopathy. Brain. 84: 460-479, 1961

13. Kristensson, K. et al: Delayed radiation lesions of the human spinal cord. Report of five cases. Acts Neuropath. (Berlin) 9: 34-44, Aug. 1967

14. Egawa, J. et al: Five cases suspected of radiological myelitis. Japan J. Clinical therapy 15: 758-762, 1970

15. Dynes, J. B. et al: Radiation myelitis. Am. J. Roent. 83: 78, 1960

16. Philips, T. L. et al: Radiation tolerance of the thoracic spinal cord. Am. J.: Radiol. 15: 758-762, 1970

17. Locksmith, J. P. et al: Permanent radiation myelopathy. Am. J. Roent. 102: 916926,1968

18. Maier, J. G. et al: Radiation myelitis of the dorsolumbar spinal cord. Radiology 93: 153-600, Jul. 1969

19. Tsuya, A. et al: Nervous disturbances secondary to therapy: (Radiation) Japan Clinic 28: 3, 84-92, 1970

20. Friedman, M.: Proc. Second National Cancer Conf., New York, Am. Cancer Soc. 1: $390-400,1954$

21. Itabashi, H. H. et al: Post-irradiation cervical myelopathy. (Report of two cases:). Neurology 7: 844-852, 1957

22. Atkins, H. L. et al: Time-dose considerations in radiation myelopathy, Acta Radiol. 5: 79-94, 1966

23. Kozuka, T. et al: A case of radiological myelitis. Cerebrum and nerve 16: 965969,1964

24. Jacobson, F.: Carcinoma of the hypopharnx. (A clinical study of 322 cases treated at Radium Hemmet from 1939-1947). Acta Radiol. 35: 1-21, 1951

25. Tan, B. C. et al: Radiation myelitis in carcinoma of the nasopharynx. Clin. Radiol. 20: 329-336, 1969

z6. Ellis, F.: Relationship of biological effect to dose-time-fractionation factors in radiotherapy. In: Current Topics in Radiation Research. Volume IV. Edited by M. Ebert and A. Howard, North-Holland Publishing Company, Amsterdam, 1968, pp. 347-397. 